\title{
Land Use Changes and Their Effects on the Value of Ecosystem Services in the Small Sanjiang Plain in China
}

\author{
Jing Chen, Bo-Ming Sun, Dan Chen, Xin Wu, Long-Zhu Guo, and Gang Wang \\ Key Laboratory of Efficient Irrigation-Drainage and Agricultural Soil-Water Environment in Southern China of Ministry of Education, \\ College of Water Conservancy and Hydropower Engineering, Hohai University, Nanjing 210098, China
}

Correspondence should be addressed to Dan Chen; 23543458@qq.com

Received 13 December 2013; Accepted 2 February 2014; Published 9 March 2014

Academic Editors: C. Galán and C. Xu

Copyright (C) 2014 Jing Chen et al. This is an open access article distributed under the Creative Commons Attribution License, which permits unrestricted use, distribution, and reproduction in any medium, provided the original work is properly cited.

The small Sanjiang plain is one of the most important commodity grain production bases and the largest fresh water wetland in China. Due to the rapid expansion of agricultural activities in the past 30 years, the contradiction between economic development and the loss of ecosystem services has become an issue of increasing concern in the area. In this study, we analysed land use changes and the loss of ecosystem services value caused by these changes. We found that cropland sprawl was predominant and occurred in forest, wetland, and grassland areas in the small Sanjiang plain from 1980 to 2010. Using a model to evaluate ecosystem services value, we calculated that the decreased values of ecosystem services were $169.88 \times 10^{8}$ Yuan from 1980 to 2000 and $120.00 \times 10^{8}$ Yuan from 2000 to 2010. All of the ecosystem services were diminished from 1980 to 2010 except for food production. Therefore, the loss of ecosystem services value should be considered by the policymakers of land use and development.

\section{Introduction}

Natural ecosystem services are those products and functions that contribute to humankind and other living organisms' survival while also improving the quality of human life [1]. The ecosystem services include food production, hydrology adjustment, climate regulation, biodiversity maintenance, gas regulation, waste treatment, erosion control, and entertainment $[2-5]$. The provision of ecosystem services is directly affected by land use [6-8]. However, because of population and economic growth, urban sprawl, and the quick expansion of industrial and agricultural activities, land use has experienced enormous changes worldwide over the past half century, from forest, grassland, and wetland to arable and building land. These changes have caused natural ecosystems to continuously be altered, destroyed, and diminished [4, $6,9-14]$. Because of the increasingly imbalanced provision of economic and natural ecosystems, the effects of land use changes on ecosystem services and their economic value have become a focus of concern for scientists, policymakers, and stakeholders over the last decade $[15,16]$.

Quantitative assessment of the effects of land use changes on the value of ecosystem services is one of the research focuses of sustainable development in science [17, 18]. Many scholars have conducted studies in different countries, regions, and basins since the 1990s [19, 20]. The effects of coastal erosion on the value of ecosystem services in Europe were quantitatively evaluated with the result that the loss of ecosystem service values was a $€ 23$ million decrease from 1975 to 2006 [21]. In Chachalacas of Mexico, due to increased urban sprawl and the decrease of grasslands and croplands from 1995 to 2006, the net loss of ecosystem service value (\$US 2006/ha/year) was approximately $\$ 7 \times 10^{5}$ [4]. Rapid land use changes in Uruguay over the past 20 years, from grassland to plantations, had seriously affected the provision of ecosystem services [22]. The analysis of land use changes and their consequent changes in ecosystem services value in the Huairou reservoir basin in China showed that in 2008 the ecosystem services value had increased $2.88 \%$ compared with that in 1990 [20]. These studies offer theories and explore land use options and the sustainable development of ecosystems in these areas.

The small Sanjiang plain is one of the most important commodity grain production bases in China. Agriculture is the leading industry in the region, and its major functions are food production and the provision of jobs and income for 
the local rural population [23]. The expansion of cropland in response to economic needs has been the main driver of agriculture in the region $[24,25]$. A rapid expansion of agricultural activities has caused an enormous change in land use in the small Sanjiang plain in the past 30 years, from a mass of forest, grassland, and wetland to farmland [26, 27], resulting in natural ecosystems being altered and destroyed and many ecological problems such as soil erosion, nonpoint source pollution, the decrease of soil fertility, and a decline in biodiversity [28-30]. Currently, the imbalanced provision of economic and ecosystem services that is a main restricted factor in social and economic sustainable development has become an issue of increasing concern in the small Sanjiang plain.

The main goals of this study are to assess land use changes in the small Sanjiang plain from 1980 to 2010 and to evaluate the effects of these changes regarding ecosystem services. We used the value of ecosystem services to estimate the effects of regional land use changes associated with agricultural development that has occurred over the past 30 years (19802010).

\section{Materials and Methods}

2.1. Study Area. The small Sanjiang plain $\left(46^{\circ} 20^{\prime} 40^{\prime \prime} \sim\right.$ $48^{\circ} 27^{\prime} 40^{\prime \prime} \mathrm{N}, 129^{\circ} 11^{\prime} 20^{\prime \prime} \sim 135^{\circ} 05^{\prime} 26^{\prime \prime} \mathrm{E}$ ) is located in Heilongjiang Province in northeast China (Figure 1). It is an alluvial plain deposited by the region's three major rivers: Heilongjiang River, Songhuajiang River, and Wusulijiang River. The area of the plain is approximately $6.9 \times 10^{4} \mathrm{~km}^{2}$ and contains 15 counties and cities. The small Sanjiang plain lies in a temperate, semihumid continental monsoon climate, and the average annual temperature is $1.8^{\circ} \mathrm{C}$ [29]. Annual precipitation is $532 \mathrm{~mm}$ in the plain (falling mainly from July to September) [30]. The average annual land surface evaporation and water surface evaporation (E601 evaporation pan) are $300-500 \mathrm{~mm}$ and $550-840 \mathrm{~mm}$, respectively. Because of three large agricultural developments and the rapid expansion of agricultural activities by 2010, farmland area accounted for $62.7 \%$ of the plain area [31], including paddy fields (45.8\% of the arable land) and dry fields (54.2\%). The main crops include rice, soybeans, corn, and wheat.

2.2. Land Use. In this study, three Landsat TM images from the years 1980, 2000, and 2010 were selected as the data source for land use. The pretreatment was shown in these images, which contained unified projection system and geometric correction (the error is not more than half a pixel) [32]. Geographical information systems (GIS 10.0) were used to analyse and build up a database of land use. Considering the land use classification system of both China and our study, we divided land use into six classes: (1) farmland (dry land and paddy land), (2) forest, (3) wetland, (4) grassland, (5) building land, and (6) wasteland.

2.3. Ecosystem Services Value (ESV). Due to a desire for more benefits and a lack of knowledge of ecosystem services value, humans have globally developed many natural ecosystems
TABLE 1: Ecosystem services value per unit area for different land use in China [14] Yuan $/ \mathrm{hm}^{2}$.

\begin{tabular}{lcccc}
\hline Ecosystem services & Cropland & Forest & Grassland & Wetland \\
\hline Gas regulation & 23.35 & 1940.11 & 673.65 & 1082.33 \\
Climate regulation & 435.63 & 1827.84 & 700.60 & 6085.31 \\
Hydrology adjustment & 345.81 & 1836.82 & 682.63 & 6035.90 \\
Erosion control & 660.18 & 1805.38 & 1005.98 & 893.71 \\
Waste treatment & 624.25 & 772.45 & 592.81 & 6467.04 \\
Biodiversity & 458.08 & 2025.44 & 839.82 & 1657.18 \\
Food & 449.10 & 148.20 & 193.11 & 161.68 \\
Raw materials & 175.15 & 1338.32 & 161.68 & 107.78 \\
Entertainment & 76.35 & 934.13 & 390.72 & 2106.28 \\
\hline Total value & 3247.90 & 12628.69 & 5241.00 & 24597.21 \\
\hline
\end{tabular}

into cropland and building land in the past, resulting in altered and destroyed functions of ecosystem services and the reduced provision of ecosystem goods and services to society $[2,11,33]$. With a more thorough understanding of the fact that ecosystem services cannot be substituted, the study of ecosystem services value has gradually garnered greater attention [20,34].

Several methods were used to estimate the value of ecosystem services, such as the simulated market approach [35], the surrogate market approach [36], energy system [37], and benefit transfer $[2,38]$. The benefit transfer method was used to estimate ecosystem services of global biomes, which was considered to be a classical method by the authors $[39,40]$. However, other scholars argued that this method was not a model for the entire world, especially China $[3,20]$. The method for estimating ecosystem services value in China was improved by interviewing 800 Chinese ecologists [14]. This method was considered to be more accurate and practicable in estimating the value of ecosystem services in China $[18,34$, 40].

In the present study, we used the benefit transfer method to estimate ESV in the Sanjiang plain based on the result of [14]. The ESV for different years can be calculated as follows:

$$
\mathrm{ESV}_{n}=\sum_{k} \sum_{f} A_{n k} \times \mathrm{VC}_{k f}
$$

where $A_{n k}$ is the area of land use for type $k$ in $n$ year; $n$ is 1980 , 2000, and 2010; $V_{k f}$ is the value coefficient of ecosystem services value for type $f\left(\mathrm{RMB}\right.$ Yuan $\left./ \mathrm{hm}^{2}\right)$ (Table 1) with land use type $k$.

Finally, to analyse the impact of land use changes on the value of ecosystem services in two periods (1980-2000, 20002010), we calculated the change rate of ecosystem services value yearly. The change rate can be calculated with the formula

$$
ð_{i-j}=\left(\frac{\mathrm{ESV}_{n_{j}}}{\mathrm{ESV}_{n_{i}}}\right)^{1 /(j-i)}-1,
$$

where $\partial_{i-j}$ is the rate of change in two periods (1980-2000, 2000-2010); $\mathrm{ESV}_{n i}$ is the value of ecosystem services in $n_{i}$ year; $n_{i}$ is 1980,2000 , and 2010 . 
TABLE 2: Land use changes from 1980 to 2010 in the small Sanjiang plain.

\begin{tabular}{|c|c|c|c|c|c|c|}
\hline \multirow{2}{*}{ Land use } & \multicolumn{3}{|c|}{ Area $\left(\times 10^{4} \mathrm{hm}^{2}\right)$} & \multicolumn{3}{|c|}{ Land use change (\%) } \\
\hline & 1980 & 2000 & 2010 & $1980-2000$ & 2000-2010 & 1980-2010 \\
\hline Cropland & 262.19 & 346.62 & 434.82 & 32.20 & 25.45 & 65.84 \\
\hline Forest & 222.57 & 215.18 & 182.83 & -3.32 & -15.03 & -17.85 \\
\hline Grassland & 24.62 & 23.12 & 2.09 & -6.12 & -90.96 & -91.51 \\
\hline Wetland & 171.74 & 95.63 & 56.29 & -44.31 & -41.14 & -67.22 \\
\hline Building land & 11.68 & 12.42 & 16.98 & 6.30 & 36.71 & 45.32 \\
\hline Wasteland & 0.30 & 0.14 & 0.10 & -53.17 & -29.00 & -66.75 \\
\hline
\end{tabular}

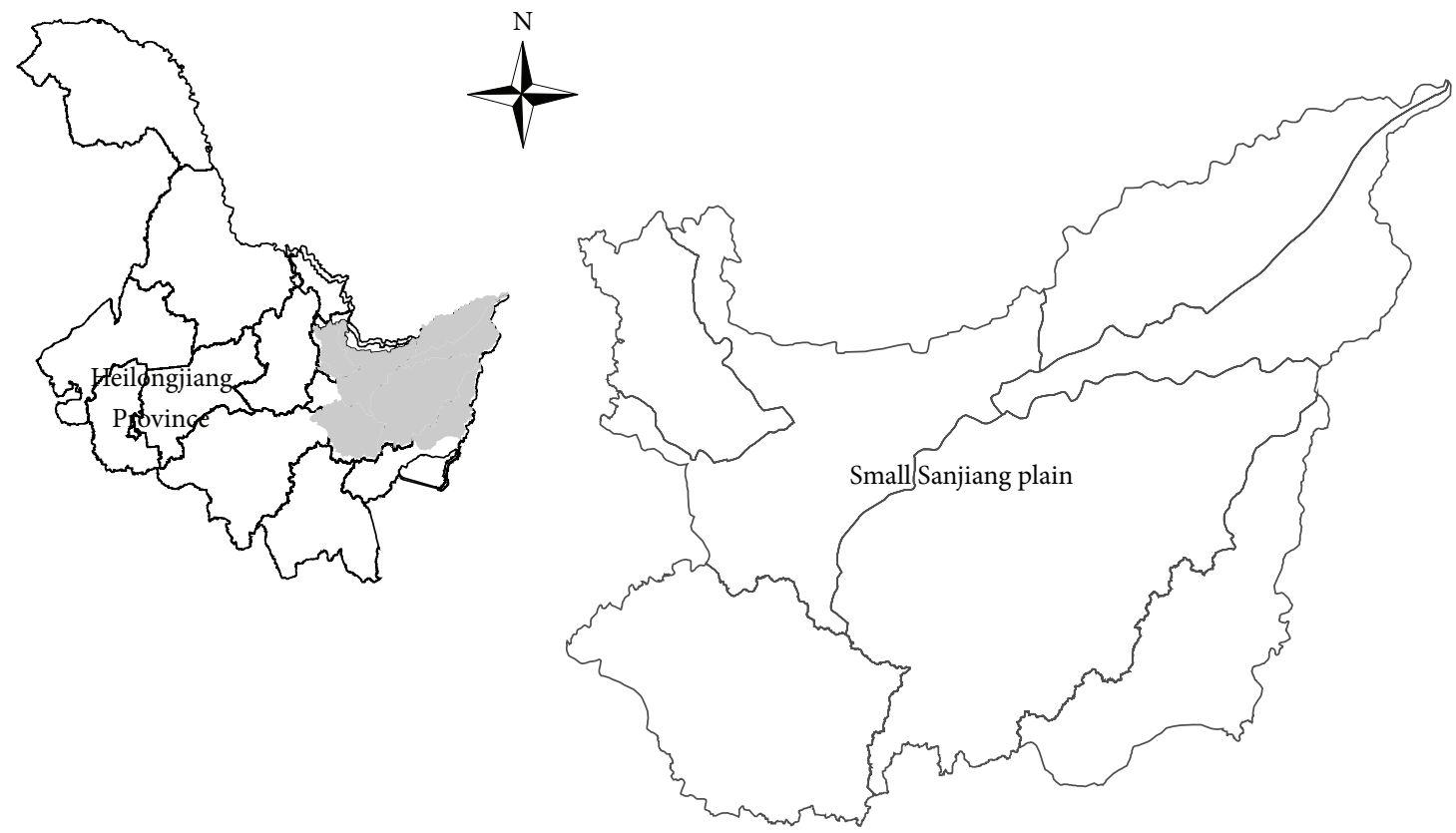

Figure 1: Location of the study area in Heilongjiang Province, northeast China.

\section{Results}

3.1. Land Use Change. Land use changes in different periods and a spatial illustration were calculated by GIS and Office Excel (Figure 2, Table 2). We found that cropland and forest always occupied the largest area in 2010, with the proportion being approximately $89 \%$, followed by wetland, building land, grassland, and wasteland. During the study period, cropland and building land had an increased area, while other land uses decreased.

The increased area of cropland was the largest, measuring at $172.63 \times 10^{4} \mathrm{hm}^{2}$ from 1980 to 2010 (Table 2), with an average annual increased rate of $2.2 \%$. Particularly during the last decade, the expansion of cropland was rapid, with an average annual increased rate of approximately $2.5 \%$ (the rate of 1.6 from 1980 to 2000). The increased area of building land was $5.3 \times 10^{4} \mathrm{hm}^{2}$ from 1980 to 2010 . The average annual increased rates of the different periods were approximately $0.3 \%(1980-2000)$ and 3.6\% (2000-2010).

The trend of wetland changes was the opposite to that of cropland, with its decreased area being the largest (Figure 2, Table 2). The area of wetland decreased from $171.74 \times 10^{4} \mathrm{hm}^{2}$ in 1980 to $56.29 \times 10^{4} \mathrm{hm}^{2}$ in 2010 , with an average annual decreased rate of approximately $2.4 \%$. From 1980 to 2000, the decreased area of wetland was approximately $67.11 \times$ $10^{4} \mathrm{hm}^{2}$. This result shows that the developed wetland had been converted to cropland.

The rate of change of grassland was the largest, with a decreased rate of approximately 92\% from 1980 to 2010 (Table 2). Grassland area was approximately $2.1 \times 10^{4} \mathrm{hm}^{2}$ in 2010, which accounted for approximately $0.3 \%$ of all the plain area. In other words, grassland is currently almost nonexistent in the small Sanjiang plain. The rate of change of forest is the lowest, with the decreased rate being $17.85 \%$ from 1980 to 2010.

3.2. Ecosystem Services Value (ESV). In this study, ecosystem services include gas regulation, climate regulation, hydrology adjustment, erosion control, waste treatment, biodiversity, food, raw materials, and entertainment (Table 1). Using the ESV model (formula (1)) and the previously described data, we estimated the ESV change in different periods in the small Sanjiang plain. The results are shown in Tables 3 and 4 . 
TABLE 3: ESV change from 1980 to 2010 in the small Sanjiang plain.

\begin{tabular}{lcccccc}
\hline & \multicolumn{3}{c}{ ESV $\left(\times 10^{8}\right.$ Yuan $)$} & \multicolumn{3}{c}{ ESV change $\left(\times 10^{8}\right.$ Yuan $)$} \\
& 1980 & 2000 & 2010 & $1980-2000$ & $2000-2010$ & 28.65 \\
\hline Cropland & 85.16 & 112.58 & 141.23 & 27.42 & -40.86 & -50.18 \\
Forest & 281.07 & 271.75 & 230.89 & -9.32 & -0.79 & -11.02 \\
Grassland & 12.91 & 12.12 & 1.10 & -187.19 & -96.77 & -283.96 \\
Wetland & 422.43 & 235.24 & 138.47 & -169.88 & -120.00 & -289.88 \\
\hline Total ESV & 801.57 & 631.69 & 511.69 & & & \\
\hline
\end{tabular}

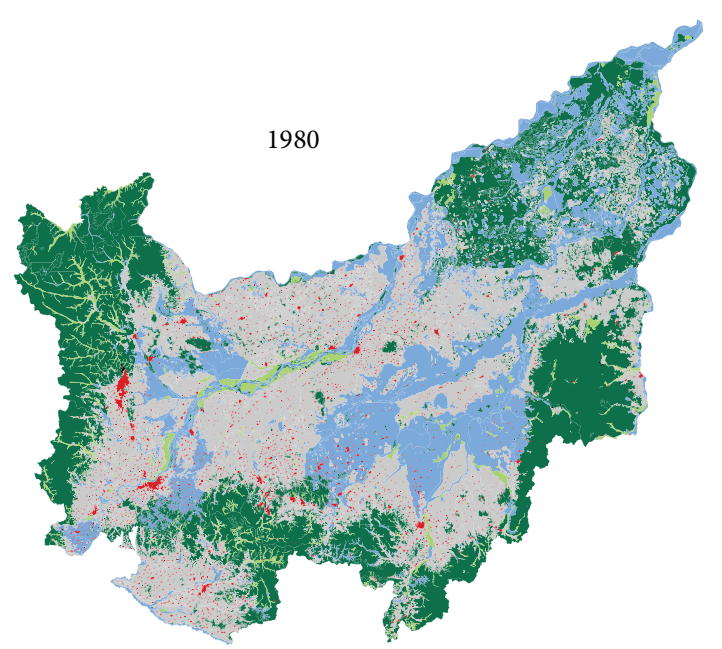

(a)

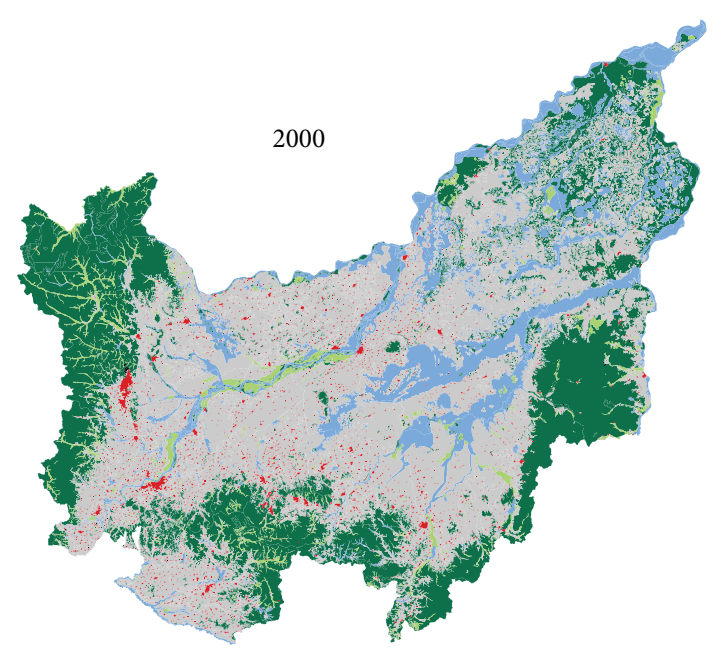

(b)

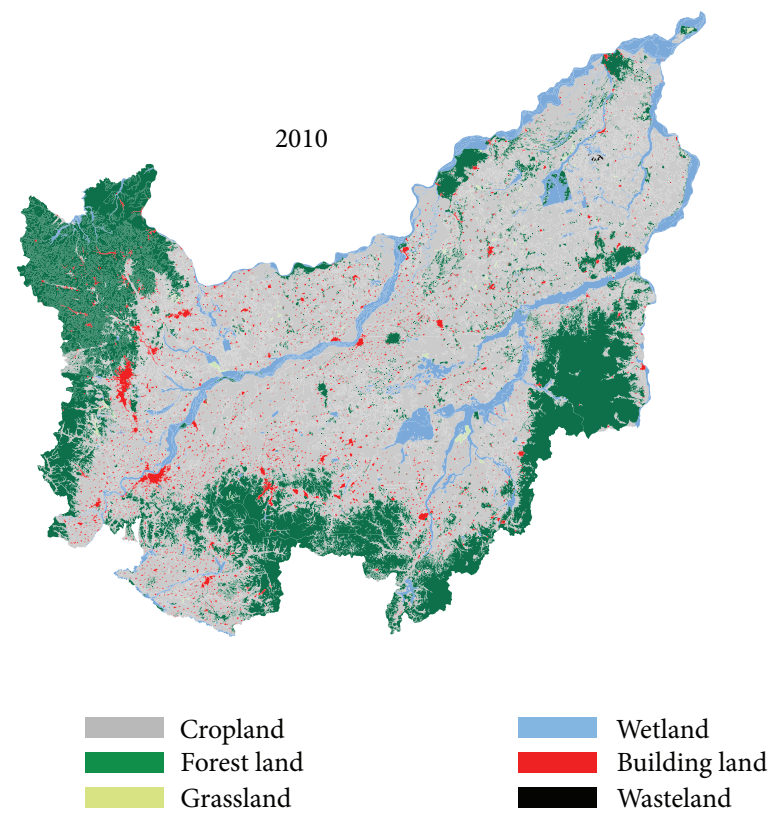

(c)

FIGURE 2: Land use changes over time in the small Sanjiang plain.

Table 3 shows that the total value of ecosystem services experienced a downtrend. The total ESV in 1980 was $801.57 \times$ $10^{8}$ Yuan. In comparison, ESV in 2000 and 2010 decreased approximately by $23.4 \%$ and $35.4 \%$, respectively. From our own calculations, we found that forest, wetland, and cropland are the main providers for the ecosystem service value. The ESVs of forest and wetland were the largest, however, with their ESVs decreasing from 1980 to 2010. Because of the rapid expansion of agriculture, the increased ESV of cropland was $56.07 \times 10^{8}$ Yuan from 1980 to 2010 . In addition, in our 
TABLE 4: Single ecosystem service value change from 1980 to 2010.

\begin{tabular}{lccc}
\hline \multirow{2}{*}{ Ecosystem services } & \multicolumn{3}{c}{ Change $\left(\times 10^{8}\right.$ Yuan $)$} \\
& $1980-2000$ & $2000-2010$ & $1980-2010$ \\
\hline Gas regulation & -9.57 & -11.75 & -21.32 \\
Climate regulation & -44.09 & -27.48 & -71.58 \\
Hydrology adjustment & -44.48 & -28.07 & -72.55 \\
Erosion control & -2.71 & -5.65 & -8.36 \\
Waste treatment & -44.61 & -23.68 & -68.29 \\
Biodiversity & -10.37 & -10.80 & -21.17 \\
Food & 2.42 & 2.44 & 4.86 \\
Raw materials & -0.35 & -3.55 & -3.90 \\
Entertainment & -16.13 & -11.46 & -27.59 \\
\hline
\end{tabular}

study, because the ecosystem services values of building land and wasteland were considered as ESV $=0$ [4], although building land and wasteland should had on gain in ESV, but loss. From our calculations (using formula (2)), Table 4 shows that the values of all single ecosystem services decreased from 1980 to 2010, except for food. The values of hydrology adjustment, climate regulation, and waste treatment were the most marked decreases. The reason for this phenomenon was that forest and wetland had been overexploited in the past 30 years. From 2000 to 2010, food production had a huge increase, with an average annual increased rate of $9.91 \%$.

\section{Conclusion and Discussion}

Looking at Figure 2 and Table 2, we observed that land use changed sharply over 30 years in the small Sanjiang plain. For more benefits and a better quality of life, humans developed natural ecosystems into industrial land and cropland in this plain. In the small Sanjiang plain, forest, grassland, and wetland decreased markedly, resulting in losses of ecosystem services and the decrease of ESV, although these changes occurred at varying degrees (Tables 3 and 4 ). The decreased ESVs of the different periods were $169.88 \times 10^{8}$ Yuan (1980$2000)$ and $120.00 \times 10^{8}$ Yuan (2000-2010).

Several factors caused these decreasing trends. On the one hand, the decreased area of forest and wetland approximately equalled the increased area of cropland and building land, and yet their ecosystem services values were higher, resulting in the ecosystem services value being decreased. On the other hand, in our study, we cannot quantitatively estimate the ecosystem services value of building land, but its area increased. Furthermore, we find that food output of cropland in Table 2 is undervalued, compared with the average of Heilongjiang Province $\left(3300 \mathrm{~kg} / \mathrm{hm}^{2}\right)$. Thus, if the food output of farmland increased to $3000 \mathrm{~kg} / \mathrm{hm}^{2}$, the decreased rate of ESV in different periods will be $155.90 \times 10^{8}$ Yuan $(1980-$ $2000)$ and $94.12 \times 10^{8}$ Yuan (2000-2010).

Because of rapid population growth, the government is currently facing an enormous challenge of securing an adequate food supply in China [41, 42]. The small Sanjiang plain is one of the most important commodity grain production bases, and its food production has an important impact on ensuring food security in China. Thus, for obvious reasons, food production is a significant driver of land use changes in the small Sanjiang plain. Land use has experienced major changes in the past 30 years, especially in the last decade. Because many forests and wetlands are replaced with cropland, the result is an altered and diminished provision of ecosystem services and functions (apart from food production) to society, such as a decline in climate and hydrology adjustment and a decrease in biodiversity decrease, among other effects [30].

The loss of wetland and forest was the most important change in the past 30 years. Because of current climate change scenarios such as an increased frequency of storms and floods $[28,43]$, it has become more important to protect against such events. The small Sanjiang plain suffered its heaviest floods in 2013 , especially in regions where the capacity to retain water is poor. Additionally, the rapid growth of wetland tourism has provided a further reason to preserve wetland and its very high economic and ecological value.

The environmental problems of land use changes are slowly beginning to be considered in the decision-making process regarding land use. For instance, one of the goals of the water conservancy development plan of the Sanjiang plain (2005-2030) was to protect the natural ecological environment and return cropland to wetland and forest. This plan noted that the natural ecosystem that provides goods and services, such as hydrology adjustment, habitat support, and soil fertility, was very important for social sustainable development. However, although the importance of ecosystem services has been acknowledged, the value of ecosystem services has thus far not been considered for any development plans. Therefore, the present study can provide the positive influence and theoretical basis for protecting the natural ecological environment, in which the contradiction is evident between sustainable ecosystem services and land exploitation.

Due to ever-increasing agricultural expansion worldwide (especially in China), land use changes may seem increasingly economically profitable. However, when land use changes deplete the ecosystem's capacities to deliver ecosystem services, long-term losses may exceed short-term gains. Land use and policy making should aim at balancing society's needs and preferences, while considering ecosystem service losses as, in the long-run, it will be beneficial for all of us if natural ecosystems are preserved and used adequately.

\section{Conflict of Interests}

The authors of the paper do not have a direct financial relation with the commercial identity mentioned in this paper that might lead to a conflict of interests.

\section{Acknowledgments}

This study was supported by the Special Funds for Public Welfare Projects of the Ministry of Water Resources of China (no. 201101022), the National Natural Science Foundation of China (no. 51109056), the Program for Distinguished Talents in Hohai University and a Project Funded by the Priority 
Academic Program Development of Jiangsu Higher Education Institutions (PAPD).

\section{References}

[1] G. C. Daily, Nature's Services: Societal Dependence on Natural Ecosystems, Island Press, 1997.

[2] R. Costanza, R. D’Arge, R. de Groot et al., "The value of the world's ecosystem services and natural capital," Nature, vol. 387, no. 6630, pp. 253-260, 1997.

[3] R.-Q. Li, M. Dong, J.-Y. Cui, L.-L. Zhang, Q.-G. Cui, and W.M. He, "Quantification of the impact of land-use changes on ecosystem services: a case study in Pingbian County, China," Environmental Monitoring and Assessment, vol. 128, no. 1-3, pp. 503-510, 2007.

[4] G. Mendoza-González, M. Martínez, D. Lithgow, O. PérezMaqueo, and P. Simonin, "Land use change and its effects on the value of ecosystem services along the coast of the Gulf of Mexico," Ecological Economics, vol. 82, pp. 23-32, 2012.

[5] R. Portela and I. Rademacher, "A dynamic model of patterns of deforestation and their effect on the ability of the Brazilian Amazonia to provide ecosystem services," Ecological Modelling, vol. 143, no. 1-2, pp. 115-146, 2001.

[6] R. S. de Groot, M. A. Wilson, and R. M. J. Boumans, "A typology for the classification, description and valuation of ecosystem functions, goods and services," Ecological Economics, vol. 41, no. 3, pp. 393-408, 2002.

[7] C. Nunes and J. Auge, Land-Use and Land-Cover Change (LUCC): Implementation Strategy, 1999.

[8] B. L. Turner, D. Skole, S. Sanderson, G. Fischer, L. Fresco, and R. Leemans, "Land-use and land-cover change, science/research plan," Global Change Report, 1995.

[9] D. Chen, J. Chen, Z. Luo, and Z. Lv, "Emergy evaluation of the natural value of water resources in Chinese rivers," Environmental Management, vol. 44, no. 2, pp. 288-297, 2009.

[10] D. Chen, M. Webber, J. Chen, and Z. Luo, "Emergy evaluation perspectives of an irrigation improvement project proposal in China," Ecological Economics, vol. 70, no. 11, pp. 2154-2162, 2011.

[11] S. McIntyre and S. Lavorel, "A conceptual model of land use effects on the structure and function of herbaceous vegetation," Agriculture, Ecosystems \& Environment, vol. 119, no. 1-2, pp. 1121, 2007.

[12] M. J. Metzger, M. D. A. Rounsevell, L. Acosta-Michlik, R. Leemans, and D. Schröter, "The vulnerability of ecosystem services to land use change," Agriculture, Ecosystems \& Environment, vol. 114, no. 1, pp. 69-85, 2006.

[13] P. M. Vitousek, H. A. Mooney, J. Lubchenco, and J. M. Melillo, "Human domination of Earth's ecosystems," Science, vol. 277, no. 5325, pp. 494-499, 1997.

[14] G. D. Xie, L. Zhen, C. X. Lu, Y. Xiao, and C. Chen, "Expert knowledge based valuation method of ecosystem services in China," Journal of Natural Resources, vol. 23, no. 5, pp. 911-919, 2008.

[15] E. F. Viglizzo and F. C. Frank, "Land-use options for Del Plata Basin in South America: tradeoffs analysis based on ecosystem service provision," Ecological Economics, vol. 57, no. 1, pp. 140151, 2006.

[16] R. L. Semwal, S. Nautiyal, K. K. Sen et al., "Patterns and ecological implications of agricultural land-use changes: a case study from central Himalaya, India," Agriculture, Ecosystems \& Environment, vol. 102, no. 1, pp. 81-92, 2004.
[17] H. Zhou, D. Xiong, and Z. Yang, "Effects of land use change on ecosystem service value in Yuanmou dry-hot valley," Transactions of the Chinese Society of Agricultural Engineering, vol. 24, no. 3, pp. 135-138, 2008.

[18] D. Wu, J. Liu, T. He, S. Wang, and R. Wang, "Profit and loss analysis on ecosystem services value based on land use change in Yellow River Delta," Transactions of the Chinese Society of Agricultural Engineering, vol. 25, no. 8, pp. 256-261, 2009.

[19] Z. Wang, B. Zhang, S. Zhang et al., "Changes of land use and of ecosystem service values in Sanjiang Plain, Northeast China," Environmental Monitoring and Assessment, vol. 112, no. 1-3, pp. 69-91, 2006.

[20] Y. Wang, X. Yu, K. He, S. Song, G. Jia, and Z. Huang, "Ecosystem services value based on land use change in Huairou reservoir watershed," Transactions of the Chinese Society of Agricultural Engineering, vol. 28, no. 5, pp. 246-251, 2012.

[21] P. Roebeling, L. Costa, L. Magalhães-Filho, and V. Tekken, "Ecosystem service value losses from coastal erosion in Europe: historical trends and future projections," Journal of Coastal Conservation, vol. 17, no. 3, pp. 389-395, 2013.

[22] P. Vihervaara, A. Marjokorpi, T. Kumpula, M. Walls, and M. Kamppinen, "Ecosystem services of fast-growing tree plantations: a case study on integrating social valuations with land-use changes in Uruguay," Forest Policy and Economics, vol. 14, no. 1, pp. 58-68, 2012.

[23] K. Song, D. Liu, Z. Wang et al., "Land use change in Sanjiang Plain and its driving forces analysis since 1954," Acta Geographica Sinica, vol. 63, no. 1, pp. 93-104, 2008.

[24] S.-F. Zhang and X.-J. Meng, "Water resources carrying capacity of the Songhua River under the background of grain production increases," Scientia Geographica Sinica, vol. 32, no. 3, pp. 342$347,2012$.

[25] S. Q. Zhang, "An empirical study on the agriculture effect to farmers income," Journal of Chongqing University, vol. 5, p. 008, 2009.

[26] G. Du, Y. Li, F. Yu, S. Zhang, and F. Yang, "Change characteristics analysis of farmland in Northern Sanjiang Plain in 2000-2009 based on remote sensing," Transactions of the Chinese Society of Agricultural Engineering, vol. 28, no. 1, pp. 225-229, 2012.

[27] Y. J. Wu, S. W. Zhang, and W. Hou, "The dynamic changes among human habitats-farmland-wetland in Naoli River Basin during the last fifty years," Resources Science, vol. 28, no. 4, pp. 78-83, 2006.

[28] M. H. Xu, "Ecological service function significance of Sanjiang Plain wetland," Territory and Natural Resources Study, vol. 1, p. 024, 2012.

[29] X. L. Liu, "Variasion trend of water and soil loss on Sanjiang Plain," Environmental Science and Management, vol. 34, no. 10, pp. 138-140, 2006.

[30] Y. F. Li, "Research on eco-environment of wetland in the Sanjiang Plain," Heilongjiang Environmental Journal, vol. 36, no. 2, pp. 19-21, 2012.

[31] Q. X. Jiang, Q. Fu, Z. L. Wang, and N. Jiang, "Spatial matching patterns of land and water resources in Sanjiang Plain," Journal of Natural Resources, vol. 26, no. 2, pp. 270-277, 2011.

[32] M. Q. Chen, B. P. Zhao, and Z. J. Luo, “The ecosystem services value change in the upper reaches of Ganjiang River based on RS and GIS," Acta Ecologica Sinica, vol. 33, no. 9, pp. 2761-2767, 2013.

[33] P. Balvanera, A. B. Pfisterer, N. Buchmann et al., "Quantifying the evidence for biodiversity effects on ecosystem functioning and services," Ecology Letters, vol. 9, no. 10, pp. 1146-1156, 2006. 
[34] J. Cheng, K. Yang, J. Zhao, and J.-P. Wu, "Impact assessment of land use change in center district of Shanghai based on ecosystem services value," China Environmental Science, vol. 29, no. 1, pp. 95-100, 2009.

[35] G. Garrod and K. G. Willis, Economic Valuation of the Environment: Methods and Case Studies, Edward Elgar, Cheltenham, UK, 1999.

[36] K.-Y. Wu, X.-Y. Ye, Z.-F. Qi, and H. Zhang, "Impacts of land use/land cover change and socioeconomic development on regional ecosystem services: the case of fast-growing Hangzhou Metropolitan area, China," Cities, vol. 31, pp. 276-284, 2012.

[37] D. C. Howard, P. J. Burgess, S. J. Butler et al., "Energyscapes: linking the energy system and ecosystem services in real landscapes," Biomass and Bioenergy, vol. 55, pp. 17-26, 2012.

[38] R. S. Rosenberger and T. D. Stanley, "Measurement, generalization, and publication: sources of error in benefit transfers and their management," Ecological Economics, vol. 60, no. 2, pp. 372378, 2006.

[39] S. Liu, R. Costanza, S. Farber, and A. Troy, "Valuing ecosystem services: theory, practice, and the need for a transdisciplinary synthesis," Annals of the New York Academy of Sciences, vol. 1185, pp. 54-78, 2010.

[40] Z.-H. Yang, H. Wang, J.-Y. Chu, and Z.-H. Zhou, "Ecosystem service valuation and spatial characteristics of Haihe Basin," Journal of Hydraulic Engineering, vol. 41, no. 9, pp. 1121-1127, 2010.

[41] D. Chen, Z. H. Luo, J. Chen, J. Kong, and D. L. She, "Emergy evaluation of a production and utilization process of irrigation water in China," The Scientific World Journal, vol. 2013, Article ID 438317, 12 pages, 2013.

[42] D. Chen, Z. H. Luo, M. Webber, J. Chen, and W. G. Wang, "Emergy evaluation of a pumping irrigation water production system in China," Frontiers of Earth Science, vol. 8, no. 1, pp. 131$141,2014$.

[43] P. J. Webster, G. J. Holland, J. A. Curry, and H.-R. Chang, "Atmospheric science: changes in tropical cyclone number, duration, and intensity in a warming environment," Science, vol. 309, no. 5742, pp. 1844-1846, 2005. 

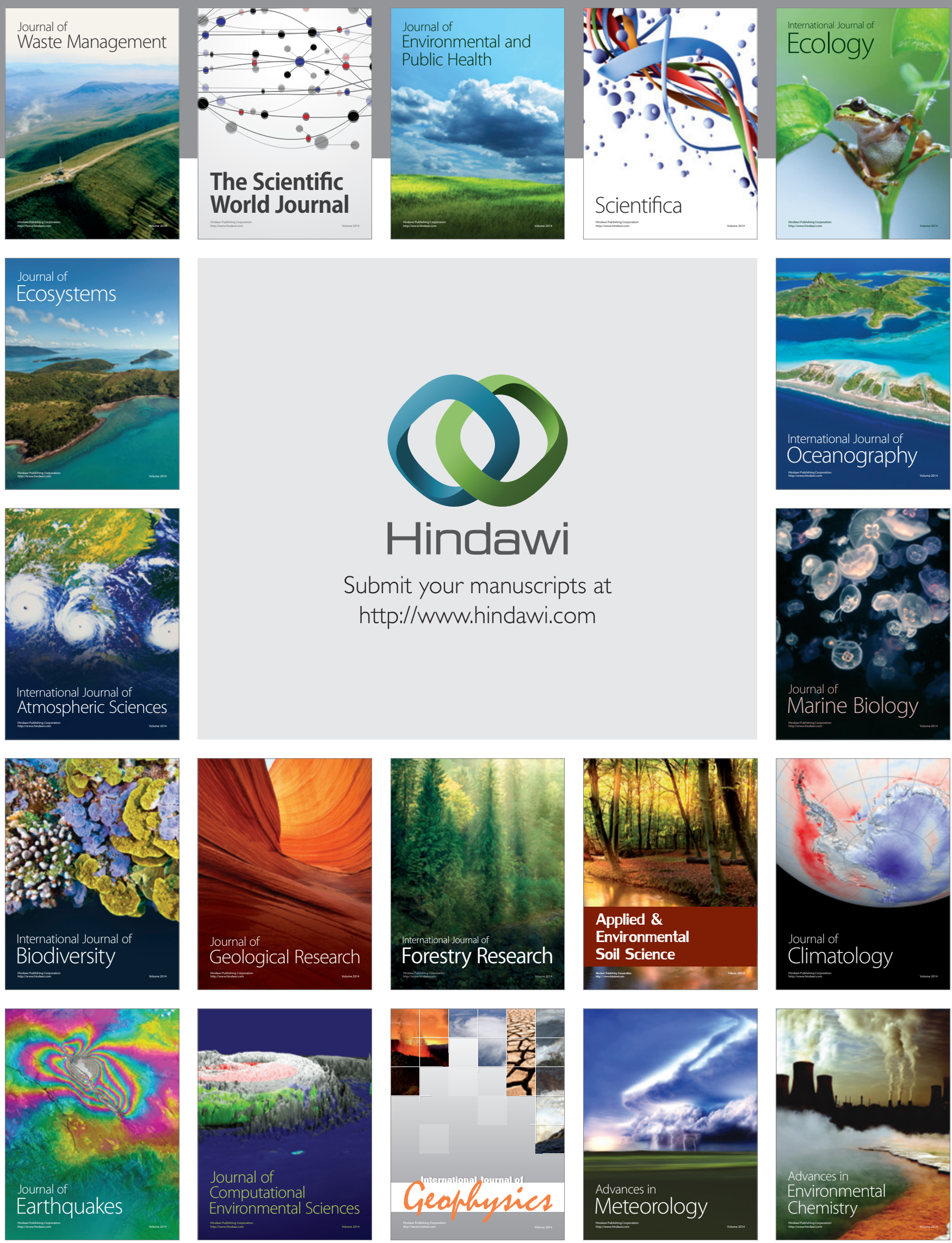